\title{
Expression of Matrix Metalloproteinase 1(MMP1) in HepatoCellular Carcinoma (HCC): Immunohistochemical and Biochemical Studies
} Mohy Eldin abdel Fattah abdel Atty Yassen*, Olfat Ali Ibrahim Hammam** and Hazem Kamel Abdel-Aziz Mohamed Sarhan***.

Chemistry Dept., Faculty of Science, Suez Canal University, Pathology Dept Theodor Bilharz Institute, Academy of Scientific Research. Medical and Radiation Research Dept., Nuclear Material Authority.

\begin{abstract}
Background: The present study aimed to evaluate the expression of Matrix Metalloproteinase-1 (MMP1) in HepatoCellular Carcinoma (HCC) by using the Immunohistochemical technique, which allows us to integrate the biological aspects of this enzymatic expression in the morphological context of HCCs.
\end{abstract}

Material and Methods: The study was performed on 70 subjects from out and in patients of Tropical medicine Department, Thiodor Billhars Institute during the period from January 2011 until June 2012. The present study included 60 patients with chronic hepatitis $\mathrm{C}$ who had undergone liver biopsy. They consisted of 42 men and 28 women with ages ranging from 36 to 66 years. The diagnosis of chronic hepatitis $\mathrm{C}$ was made on the basis of positivity for anti-HCV (by the second generation ELISA), and confirmed by HCVRNA reverse transcription polymerase chain reaction (RT-PCR). Patients were divided into four groups: Group I: included 10 normal persons with no history of liver disease with normal liver enzymes and free ultrasonographic finding as normal control. It included 6 males, 4 females, with ages ranging from 34 to 48 years. Group II: included $20 \mathrm{HCV}$ infected patients without cirrhotic changes. It included 11 males, 9 females, with ages ranging from 39 to 53 years. Group III: included $20 \mathrm{HCV}$ infected patients with liver cirrhosis, 12 males, 8 females, with ages ranging from 48-63 years. Group IV: included $20 \mathrm{HCV}$ infected patients with HCC, 16 males, 4 females, with ages ranging from 53-64 years.

Results: Blood Picture, (Hb, WBCs, RBCs, Plts, PC and ESR). Liver Function Test (ALT, AST, ALB, GGT, ALP, T. BIL and D. BIL). Matrix Metalloprotenase 1(MMP1) Measurements: Serum MMP1. Histopathological investigation Including histopathological changes in the liver tissue.

Conclusion: our results suggest that MMP-1 is overexpressed in a large proportion of patients with HCC and the high expression level of protein correlated with the disease progression and poor clinical outcome in HCC. Furthermore, MMP-1 high expression proved to be a risk factor for tumor recurrence and independent molecular marker of prognosis in HCC and may become a novel target in the strategies for the prediction of tumor progression and prognosis of this disease.

\section{Key words: Patients, HCV, Cirrhosis, HCC, and MMP-1}

\section{Introduction:}

Hepatocellular carcinoma (HCC) is the fifth most common cancer and sixth leading cause of death among cancers worldwide (1), and $\mathrm{HCC}$ is a heterogeneous group in terms of biological behavior and molecular profiles (2). Recent studies support that tumors may be initiated and maintained by a small population of cells that have stem-like features, and this highly tumorigenic cell subset within the tumor bulk has been considered as cancer stem cell (3). Invasion is a characteristic feature of HCC, it frequently shows early invasion into blood vessels as well as intrahepatic metastasis and later shows extrahepatic metastasis.
Tommaso, (4), reported that, Hepatocellular carcinoma (HCC) is a common form of cancer that arises from hepatocytes and whose risk may be affected by several known environmental factors, including hepatitis viruses, alcohol, cigarette smoking, and others. Rare monogenic syndromes, such as alpha1-antitrypsin deficiency, glycogen storage disease type I, hemochromatosis, acute intermittent and cutanea tarda porphyria, as well as hereditary tyrosinemia type I are associated with a high risk of HCC. Several common conditions or diseases inherited as polygenic traits e.g. autoimmune hepatitis, type 2 diabetes, a family history of HCC, hypothyroidism, and non-alcoholic steatohepatitis also show an increased risk of HCC compared to the general population. Hepatitis $\mathrm{C}$ infection 
remains the greatest risk factor for the development of HCC. Approximately 170 million people worldwide are seropositive for anti-HCV and, of these, an estimated 127 million are chronically infected (5). Markers of $\mathrm{HCV}$ infection are found in $28-76 \%$ of HCC cases in Europe (with an increasing gradient from north to south) and in $80-90 \%$ of patients with HCC presenting in Japan. Methods of HCV viral transmission are complex. In the United States, $\mathrm{HCV}$ infection is largely associated with intravenous drug use and sexual contact, which account for approximately $85 \%$ of infections (6). In 1978, cirrhosis was defined by the World Health Organization as a diffuse process characterized by fibrosis and the conversion of normal liver architecture into structurally abnormal nodules (7). The most common cause of hepatic fibrosis is alcohol abuse, which leads to repeated liver injury/damage and degeneration of liver parenchymal tissue. Apart from alcohol abuse, other factors have the potential to induce hepatic fibrogenesis. Cirrhosis and chronic repetitive hepatic injury, as are manifest in chronic active hepatitis, are associated with the majority (80\%) of HCC cases and represent a major underlying factor predisposing the development of HCC (8).

In 2004, Matsunaga et al. (9) demonstrated that the expression of MMP-1 in most of the HCC tissues was equal or low compared with those in the surrounding nontumor tissues, although mixed expression pattern was recognized in some HCC tissues. The difference of MMP-1 expression was not related with the histological differentiation of HCC and the condition of non-cancerous area. These findings suggested little association of the clinicopathological findings of HCC with the histological expression of MMP-1. However, in 2009, Altadill et al. (10) reported that MMP-1 is mainly expressed by stromal cells of HCC tissues. A positive correlation between MMP-1 expression and larger size tumors was found. Moreover, they also found that all HCC patients showing elevated MMP-1 expression in stromal cells presented a poor prognosis.

\section{Material and Methods:}

\section{I-Materials:}

The study was performed on 70 subjects from out and in patients of Tropical medicine Department, Thiodor Billhars Institute during the period from January 2011 until June 2012.
The present study included 60 patients with chronic hepatitis $\mathrm{C}$ who had undergone liver biopsy.

They consisted of 42 men and 28 women with ages ranging from 36 to 66 years. The diagnosis of chronic hepatitis $\mathrm{C}$ was made on the basis of positivity for anti-HCV (by the second generation ELISA), and confirmed by HCV-RNA reverse transcription polymerase chain reaction (RT-PCR).

Patients with HBV infection or auto antibodies (antinuclear antibody, anti-smooth muscle antibody, and antimitochondrial antibody, or history of alcohol abuse were excluded from the study.

Patients were divided into four groups:

Group I: included 10 normal persons with no history of liver disease with normal liver enzymes and free ultrasonographic finding as normal control. It included 6 males, 4 females, with ages ranging from 34 to 48 years.

Group II: included $20 \mathrm{HCV}$ infected patients without cirrhotic changes. It included 11 males, 9 females, with ages ranging from 39 to 53 years.

Group III: included $20 \mathrm{HCV}$ infected patients with liver cirrhosis, 12 males, 8 females, with ages ranging from 48-63 years.

Group IV: included $20 \mathrm{HCV}$ infected patients with HCC, 16 males, 4 females, with ages ranging from 53-64 years.

A detailed history and physical examination of the patients were carried out with special emphasis on history of schistosomiasis, prior parenteral therapy, infective hepatitis and jaundice or other signs of liver cell failure. Complete clinical examination, which includes the manifestations of hepatitis and liver cell failure such as jaundice, hepatomegaly, tenderness in the right hypochondrium, ascites, splenomegaly, lower limb edema as well as abdominal ultrasonography was also done side by side with routine laboratory investigations.

Biochemical and Serological Tests: Ten milliliters of fasted venous blood (6 Hours of fasting) were taken from each subject participating in the study $1.0 \mathrm{ml}$ of blood added into EDTA tubes for determination of Hemoglobin, RBCs, WBCs, Platlets and Erethrocytes Sedimentation Rate (ESR) and the rest of the blood was left to clot. Serum were separated by centrifugation and stored at $-20^{\circ} \mathrm{c}$ for analysis of:

Markers of Hepatitis Virus: Hepatitis B surface antigen ( $\mathrm{HBsAg}$ ), hepatitis B core antibody 
( $\mathrm{HbcAb}$ ), hepatitis $\mathrm{C}$ virus antibody (HCV-Ab), and hepatitis $\mathrm{C}$ virus RNA (HCV-RNA).

Markers of Hepatitis Virus: HCV antibodies were detected using a third generation enzyme-linked immunosorbent assay (Sorin Biomedica Diagnostics, Italy), (11). Serological assay for HBV markers (HbsAg and anti-HBc) were performed by a direct noncompetitive sandwich assay (DiaSorin, Italy) based on ELISA technique (12).

Blood Picture: Hemoglobin $(\mathrm{Hb})$, white blood cell counts (WBCs), red blood cell counts (RBCs), platelets (Plt) and Erethrocytes Sedimentation Rate (ESR).

Blood Picture was done on Coulter Counter T890, (Coulter Counter, Harpenden, UK) (13).

Liver Function Test: alanine aminotransferase (ALAT), aspartate aminotransferase (ASAT), albumin (ALB), $\gamma$-glutamyl Transferase (GGT), Alkaline Phosphatase (ALP), Total bilirubin ( $\mathrm{T}$. BIL) and Direct bilirubin (D. BIL). Liver function tests were performed using a Beckman Auto-analyzer (Synchron CX4, USA). A diazotization method used for determination of serum total bilirubin (14). Activities of ALT and AST were measured by the enzyme rate method (15), Albumin was determined according to Pinnell and Northam, (16). Prothrombin time was determined using standard thromboplastin method (17).

Matrix Metalloprotenase 1(MMP1) Measurements: Serum MMP1.

Liver Biopsy: Liver biopsy samples were obtained for diagnostic purposes percutaneously, in some cases HCC was diagnosed guided by ultrascan using a Toshiba SSA 240, an apparatus with a $3.5 \mathrm{MHz}$ probe.

\section{II-METHODS:}

Liver biopsies will proceed in standard method to paraffin blocks and stained with:

1- H\&E stain for histopathological diagnosis of cases.

2- Masson Trichrome to evaluate fibrosis.

3- Immunohistochemical stain using monoclonal antibody for Matrix Metallo- proteinase 1(MMP1) according to Hsu and Raine (18).

\section{II.1-Immunohistochemical Procedure:}

Tissue sections from all different studied bladder lesions were immunohistochemically stained for MMP1 using the standard avidinbiotin peroxidase complex (APC) according to Hsu and Raine (18) method through the following procedures:

A. Preparation of slides. B. Deparaffinization and Rehydration of the Sections. C. Blocking Endogenous Peroxidase Activity. D. Antigen Retrieval. E. Applications of primary antibody.
F. Counter stain. G. Dehydration of the sections. $\mathrm{H}$. Mounting procedures.

II.2-Histopathological invistigation:

Including histopathological changes in the liver tissue.

A. Preservation and Processing. B. Sectioning.

C. Histopathological study.

Liver sections were microscopically studied to evaluate the pathological changes including portal tracts and the schistosomal granulomatous reactions.

II.3- Biochemical parameters:

Including liver function tests (ALAT, ASAT, ALB, GGT, ALP, T. BIL and D. BIL).

II.4- Statistical analysis:

Results were expressed as the mean \pm SE. Data were statistically analyzed for variance and the least significant difference (LSD) using one way analysis of variance (ANOVA) according to Snedecor and Cochron, (19). SPSS version 13 was used for analysis.

\section{$\underline{\text { Results }}$}

I- The results of biochemical parameters of serum liver Functions of all Patients were documented in Table (1):

Estimation of serum liver function tests (ALAT, ASAT, ALB, GGT, ALP, T. BIL and D. BIL):

In the present data, a high significant increase in all parameter of liver functions enzymes activity (ASAT, ALAT, ALP, $\gamma$ GT, T. BIL and T. BIL) and high significant decrease of albumin in HCV, Cirrhosis and MMP1 groups versus the uninfected negative control group. An amelioration in all parameters of liver functions enzymes activity of $\mathrm{HCV}$ as comparing to Cirrhosis as comparing to MMP1groups.

II- The results of Complete Blood Picture of all Patients were documented in Table (2):

In the present data, high significant increase in all parameter of $\mathrm{CBC}$ (PC, WBCs, RBCs, $\mathrm{Hb} \%$, Platelets) and ESR in HCV, Cirrhosis and MMP1 groups versus the uninfected negative control group. An amelioration in all parameters of $\mathrm{CBC}$ of $\mathrm{HCV}$ as comparing to Cirrhosis and Cirrhosis as comparing to MMP1groups.

III- The results of Matrix Metalloproteinase 1(MMP1) of all Patients were documented in Table (3):

The results demonstrated an increasing of MMP1 with a high significant differences ( $\mathbf{p}<$ 0.01) in HCC group as comparing to each of 
normal control HCV and Cirrhosis groups, also increasing of MMP1 with high significant differences $(\mathbf{p}<\mathbf{0 . 0 1})$ in Cirrhosis groups as comparing to each of normal control and $\mathrm{HCV}$ groups. On the other hand there is increase of MMP1 in HCV group but with no significant differences as comparing to normal control group.

VII- Histopathological grading and Staging of the studied HCV, Cirrhosis and HCC groups:

The Evaluation demonstrated that, in $\mathrm{HCV}$ group grade I and II represent $55 \%$ and
$45 \%$ respectively, while there is no grade III. On the other hand there are no grade I and II, while grade III represent $100 \%$ in Cirrhosis group. HCC grade I,II and III reaches 50\%, $40 \%$ and $10 \%$ respectively as shown in (Table 4 and 5).

Histopathological Staging of the studied HCV represent 55\% and $45 \%$ for the Staging I and II respectively, while there is no Staging III. On the other hand, Staging III in Cirrhosis group represent $100 \%$ and there are no Staging I and II as shown in (Table 6).

Table (1): Shows the values of liver functions in each groups and the effects of diseases on the liver.

\begin{tabular}{|c|c|c|c|c|c|c|c|c|}
\hline \multicolumn{2}{|c|}{ Groups } & $\begin{array}{l}\text { ASAT } \\
\text { (U/L) }\end{array}$ & $\begin{array}{l}\text { SALAT } \\
\text { (U/L) }\end{array}$ & $\begin{array}{l}\text { ALP } \\
(\mathbf{U} / \mathbf{L})\end{array}$ & $\begin{array}{l}\gamma \mathbf{G T} \\
(\mathbf{U} / \mathbf{L})\end{array}$ & $\begin{array}{l}\text { Alb } \\
(\mathbf{m g} / \mathbf{d l})\end{array}$ & D. Bil & T. Bil \\
\hline $\begin{array}{c}\text { Normal control } \\
n=10\end{array}$ & $\begin{array}{l}\text { Mean } \\
\pm \mathrm{SE}\end{array}$ & $\begin{array}{l}18.60 \\
\pm 2.01\end{array}$ & $\begin{array}{l}21.80 \\
\pm 2.08\end{array}$ & $\begin{array}{l}99.50 \\
\pm 8.81\end{array}$ & $\begin{array}{l}20.00 \\
\pm 2.08\end{array}$ & $\begin{array}{l}4.08 \\
\pm 0.39\end{array}$ & $\begin{array}{l}0.190 \\
\pm 0.02\end{array}$ & $\begin{array}{l}0.806 \\
\pm 0.09\end{array}$ \\
\hline $\begin{array}{l}\text { patients with } \\
\quad \begin{array}{l}\mathrm{HCV} \\
\mathrm{n}=20\end{array}\end{array}$ & $\begin{array}{l}\text { Mean } \\
\pm \mathrm{SE}\end{array}$ & $\begin{array}{l}a^{\prime} \\
99.00 \\
\pm 11.38\end{array}$ & $\begin{array}{l}a^{\prime} \\
108.80 \\
\pm 13.25\end{array}$ & $\begin{array}{l}a^{\prime} d^{\prime} \\
199.86 \\
\pm 11.18\end{array}$ & $\begin{array}{r}a^{\prime} \\
115.00 \\
\pm 11.05\end{array}$ & $\begin{array}{l}\text { a c d' } \\
3.45 \\
\pm .36\end{array}$ & $\begin{array}{l}a^{\prime} d^{\prime} \\
1.826 \\
\pm .28\end{array}$ & $\begin{array}{l}a^{\prime} c^{\prime} d^{\prime} \\
1.28 \\
\pm .14\end{array}$ \\
\hline $\begin{array}{l}\text { patients with } \\
\text { chronic } \\
\text { cirrhosis } n=20\end{array}$ & $\begin{array}{l}\text { Mean } \\
\pm \text { SE }\end{array}$ & $\begin{array}{l}a^{\prime} \\
74.80 \\
\pm 9.8\end{array}$ & $\begin{array}{l}a^{\prime} \\
73.40 \\
\pm 8.3\end{array}$ & $\begin{array}{l}a^{\prime} d^{\prime} \\
178.53 \\
\pm 8.7\end{array}$ & $\begin{array}{l}a^{\prime} \\
121.800 \\
\pm 19.1\end{array}$ & $\begin{array}{l}a^{\prime} b \\
3.12 \\
\pm .31\end{array}$ & $\begin{array}{l}a^{\prime} \\
2.036 \\
\pm .32\end{array}$ & $\begin{array}{l}a^{\prime} b^{\prime} \\
3.305 \\
\pm .29\end{array}$ \\
\hline $\begin{array}{l}\text { patients with } \\
\qquad \begin{array}{c}\text { (HCC) } \\
\text { n=20 }\end{array}\end{array}$ & $\begin{array}{l}\text { Mean } \\
\pm \text { SE }\end{array}$ & $\begin{array}{l}a^{\prime} \\
90.40 \\
\pm 5.8\end{array}$ & $\begin{array}{l}a^{\prime} \\
102.88 \\
\pm 10.2\end{array}$ & $\begin{array}{l}a^{\prime} b^{\prime} c^{\prime} \\
295.68 \\
\pm 22.9\end{array}$ & $\begin{array}{l}a^{\prime} \\
135.28 \\
\pm 11.9\end{array}$ & $\begin{array}{l}a^{\prime} b^{\prime} \\
2.91 \\
\pm .29\end{array}$ & $\begin{array}{l}a^{\prime} b^{\prime} \\
2.150 \\
\pm .25\end{array}$ & $\begin{array}{l}a^{\prime} b^{\prime} \\
3.572 \\
\pm .25\end{array}$ \\
\hline
\end{tabular}

- Each value represents the mean of number of patients in each group $\pm \mathrm{SE}$. $a=p<0.05 \& a^{\prime}=p<0.01$ Significant different from normal control group.

$b=p<0.05 \& b^{\prime}=p<0.01$ Significant different from HCV Group.

$c=p<0.05 \& c^{\prime}=p<0.01$ Significant different from Cirrhosis group.

$d=p<0.05 \& d^{\prime}=p<0.01$ Significant different from HCC group. 
Table (2): Shows the values of Complete Blood Picture in each groups and the effects of diseases on the liver.

\begin{tabular}{|c|c|c|c|c|c|c|c|}
\hline \multicolumn{2}{|l|}{ Groups } & PC & WBCs & RBCs & Hb\% & Platelets & ESR \\
\hline $\begin{array}{c}\text { Normal control } \\
\quad \mathbf{n}=\mathbf{1 0}\end{array}$ & $\begin{array}{l}\text { Mean } \\
\pm \mathrm{SE}\end{array}$ & $\begin{array}{l}93.40 \\
\pm 1.95\end{array}$ & $\begin{array}{l}5.60 \\
\pm .238\end{array}$ & $\begin{array}{l}5.20 \\
\pm .075\end{array}$ & $\begin{array}{l}14.800 \\
\pm 1.32\end{array}$ & $\begin{array}{l}197.20 \\
\pm 16.61\end{array}$ & $\begin{array}{r}10.800 \\
\pm 1.14\end{array}$ \\
\hline $\begin{array}{l}\text { patients with } \mathrm{HCV} \\
\qquad \mathrm{n}=15\end{array}$ & $\begin{array}{l}\text { Mean } \\
\pm \mathrm{SE}\end{array}$ & $\begin{array}{l}c^{\prime} d^{\prime} \\
82.33 \\
\pm 7.05\end{array}$ & $\begin{array}{l}\text { a c d' } \\
5.12 \\
\pm .405\end{array}$ & $\begin{array}{l}c^{\prime} d^{\prime} \\
4.24 \\
\pm .316\end{array}$ & $\begin{array}{l}\text { a c d' } \\
12.16 \\
\pm 1.18\end{array}$ & $\begin{array}{l}a^{\prime} c d^{\prime} \\
144.40 \\
\pm 5.40\end{array}$ & $\begin{array}{l}\text { a c d' } \\
17.46 \\
\pm 1.85\end{array}$ \\
\hline $\begin{array}{l}\text { patients with chronic } \\
\text { cirrhosis } n=15\end{array}$ & $\begin{array}{l}\text { Mean } \\
\pm \mathrm{SE}\end{array}$ & $\begin{array}{l}a^{\prime} b^{\prime} \\
69.466 \\
\pm 6.78\end{array}$ & $\begin{array}{l}a^{\prime} b^{\prime} \\
4.39 \\
\pm .343\end{array}$ & $\begin{array}{l}a^{\prime} b^{\prime} \\
3.94 \\
\pm .120\end{array}$ & $\begin{array}{l}a^{\prime} b d \\
11.46 \\
\pm .080\end{array}$ & $\begin{array}{l}a^{\prime} b^{\prime} d^{\prime} \\
131.40 \\
\pm 5.28\end{array}$ & $\begin{array}{l}a^{\prime} b^{\prime} d^{\prime} \\
29.40 \\
\pm 3.01\end{array}$ \\
\hline $\begin{array}{c}\text { patients with (HCC) } \\
\mathbf{n}=20\end{array}$ & $\begin{array}{l}\text { Mean } \\
\pm \mathrm{SE}\end{array}$ & $\begin{array}{l}a^{\prime} b^{\prime} \\
64.76 \\
\pm 5.59\end{array}$ & $\begin{array}{l}a^{\prime} b^{\prime} c^{\prime} \\
3.87 \\
\pm .265\end{array}$ & $\begin{array}{l}a^{\prime} b^{\prime} \\
3.63 \\
\pm .280\end{array}$ & $\begin{array}{l}a^{\prime} b^{\prime} c \\
10.23 \\
\pm 1.06\end{array}$ & $\begin{array}{l}a^{\prime} b^{\prime} c^{\prime} \\
101.08 \\
\pm 9.32\end{array}$ & $\begin{array}{l}a^{\prime} b^{\prime} c^{\prime} \\
54.96 \\
\pm 4.91\end{array}$ \\
\hline
\end{tabular}

- Each value represents the mean of number of patients in each group $\pm \mathrm{SE}$. $\mathrm{a}=\boldsymbol{p}<0.05 \& \mathrm{a}^{\prime}=p<0.01$ Significant different from normal control group.

$b=p<0.05 \& b^{\prime}=p<0.01$ Significant different from HCV Group. $c=p<0.05 \& c^{\prime}=p<0.01$ Significant different from Cirrhosis group. $d=p<0.05 \& d^{\prime}=p<0.01$ Significant different from HCC group.

Table (3): Shows the Mean Difference of Matrix Metalloproteinase 1(MMP1).

\begin{tabular}{|c|c|c|}
\hline \multicolumn{2}{|c|}{ Groups } & \\
\hline $\begin{array}{c}\text { Control } \\
n=10\end{array}$ & Mean \pm SE & $1.6 \pm .066$ \\
\hline $\begin{array}{l}\text { HCV } \\
n=20\end{array}$ & Mean \pm SE & $\begin{array}{l}c^{\prime} d^{\prime} \\
2.600 \pm .180\end{array}$ \\
\hline $\begin{array}{c}\text { cirrhosis } \\
\mathbf{n}=\mathbf{2 0}\end{array}$ & Mean \pm SE & $\begin{array}{l}a^{\prime} b^{\prime} \\
10.200 \pm 1.07\end{array}$ \\
\hline $\begin{array}{l}(\mathrm{HCC}) \\
\mathbf{n}=20\end{array}$ & Mean \pm SE & $\begin{array}{l}a^{\prime} b^{\prime} c^{\prime} \\
22.360 \pm 2.91\end{array}$ \\
\hline
\end{tabular}

- Each value represents the mean of number of patients in each group $\pm \mathrm{SE}$. $a^{\prime}=p<0.01$ Significant different from normal control group.

$b^{\prime}=p<0.01$ Significant different from HCV Group.

$c^{\prime}=p<0.01$ Significant different from Cirrhosis group.

$\mathrm{d}^{\prime}=p<0.01$ Significant different from HCC group. 
Table (4): Shows the Histopathological grading of the studied HCV and Cirrhosis groups:

\begin{tabular}{|r|l|c|c|}
\hline \multirow{2}{*}{ Groups } & \multicolumn{3}{|l|}{ Grades } \\
\cline { 2 - 4 } & $\begin{array}{l}\text { Grade } \\
\text { degree }\end{array}$ & $\begin{array}{l}\text { Number } \\
\text { s }\end{array}$ & $\begin{array}{r}\text { Percent } \\
(\%)\end{array}$ \\
\hline $\begin{array}{r}\text { patients with } \\
\text { HCV n=20 }\end{array}$ & Grade I & $\mathbf{1 1}$ & $\mathbf{5 5 \%}$ \\
\cline { 2 - 4 } & Grade II & $\mathbf{9}$ & $\mathbf{4 5 \%}$ \\
\cline { 2 - 4 } & Grade III & $\mathbf{0}$ & $\mathbf{0 \%}$ \\
\hline $\begin{array}{r}\text { patients with } \\
\text { chronic cirrhosis } \\
\mathbf{n = 2 0}\end{array}$ & Grade I & $\mathbf{0}$ & $\mathbf{0 \%}$ \\
\cline { 2 - 4 } & Grade II & $\mathbf{0}$ & $\mathbf{0 \%}$ \\
\hline
\end{tabular}

Table (5): Shows the Histopathological grading of the studied HCC group:

\begin{tabular}{|c|c|c|c|}
\hline Group & \multicolumn{3}{|c|}{ HCC Grade } \\
\hline patients with & $\begin{array}{c}\text { HCC Grade } \\
\text { degree }\end{array}$ & $\begin{array}{c}\text { Number } \\
\text { s }\end{array}$ & $\begin{array}{c}\text { Percent } \\
(\%)\end{array}$ \\
\cline { 2 - 4 } & Grade I & $\mathbf{7}$ & $\mathbf{3 5 \%}$ \\
\cline { 2 - 4 } $\mathbf{n}=\mathbf{2 0}$ & Grade II & $\mathbf{9}$ & $\mathbf{4 5 \%}$ \\
\cline { 2 - 4 } & Grade III & $\mathbf{4}$ & $\mathbf{2 0 \%}$ \\
\hline
\end{tabular}

Table (6): Shows the Histopathological Staging of the studied HCV and Cirrhosis groups:

\begin{tabular}{|c|c|c|c|}
\hline Groups & \multicolumn{3}{|c|}{ Stages } \\
\hline \multirow{4}{*}{$\begin{array}{c}\text { patients with } \\
\text { HCV n=20 }\end{array}$} & $\begin{array}{c}\text { Stages } \\
\text { degree }\end{array}$ & $\begin{array}{c}\text { Number } \\
\text { s }\end{array}$ & $\begin{array}{r}\text { Percent } \\
(\%)\end{array}$ \\
\cline { 2 - 4 } & Stages I & $\mathbf{1 0}$ & $\mathbf{5 0 \%}$ \\
\cline { 2 - 4 } & Stages II & $\mathbf{8}$ & $\mathbf{4 0 \%}$ \\
\cline { 2 - 4 } & Stages III & $\mathbf{2}$ & $\mathbf{1 0 \%}$ \\
\hline $\begin{array}{c}\text { patients with } \\
\text { chronic cirrhosis } \\
\text { n=20 }\end{array}$ & Stages I & $\mathbf{0}$ & $\mathbf{0 \%}$ \\
\cline { 2 - 4 } & Stages II & $\mathbf{0}$ & $\mathbf{0 \%}$ \\
\cline { 2 - 4 } & Stages III & $\mathbf{2 0}$ & $\mathbf{1 0 0} \%$ \\
\hline
\end{tabular}


Figures showes Histopathological grading and Staging of the studied HCV, Cirrhosis and HCC groups comparing to control group:

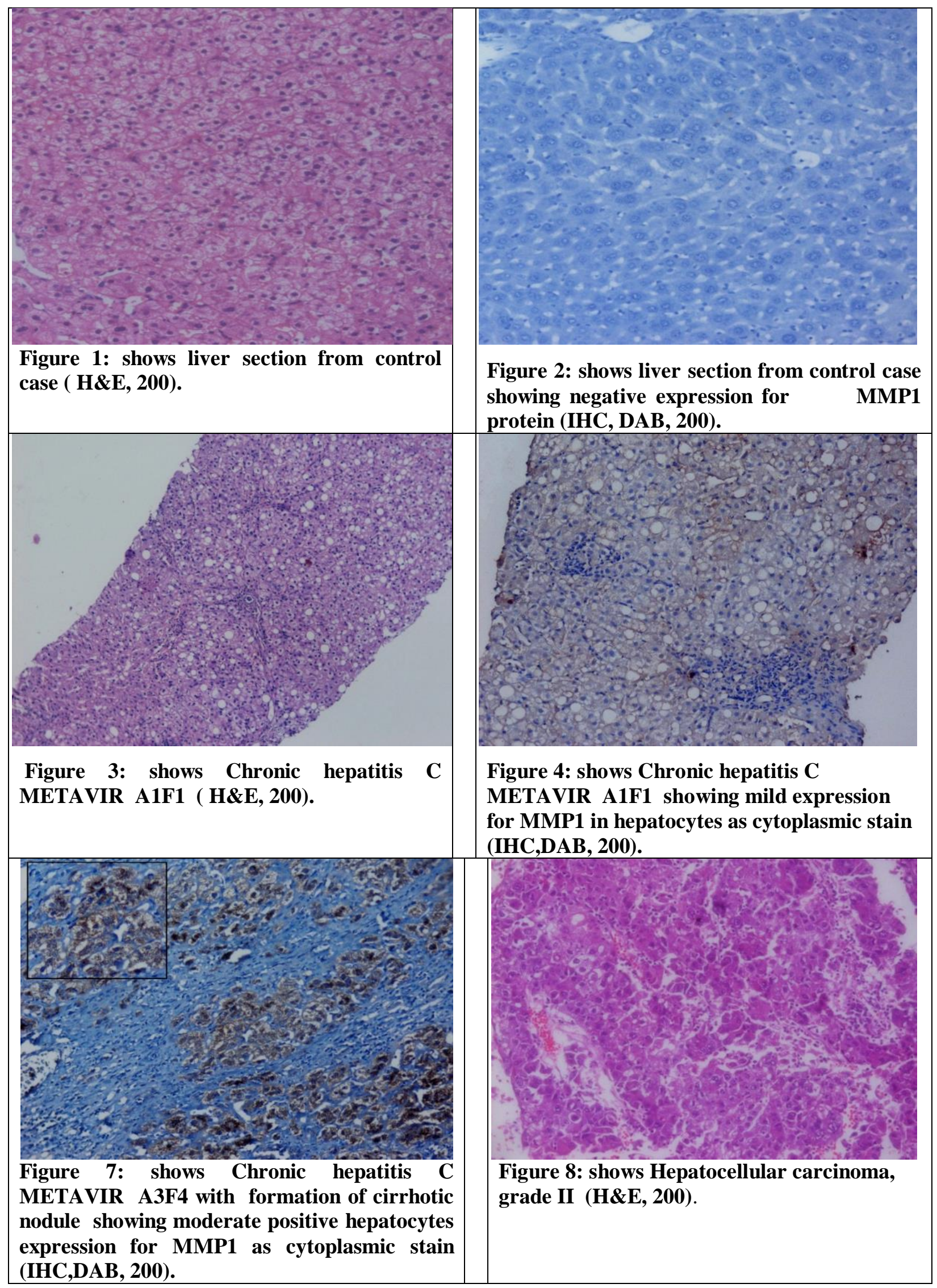




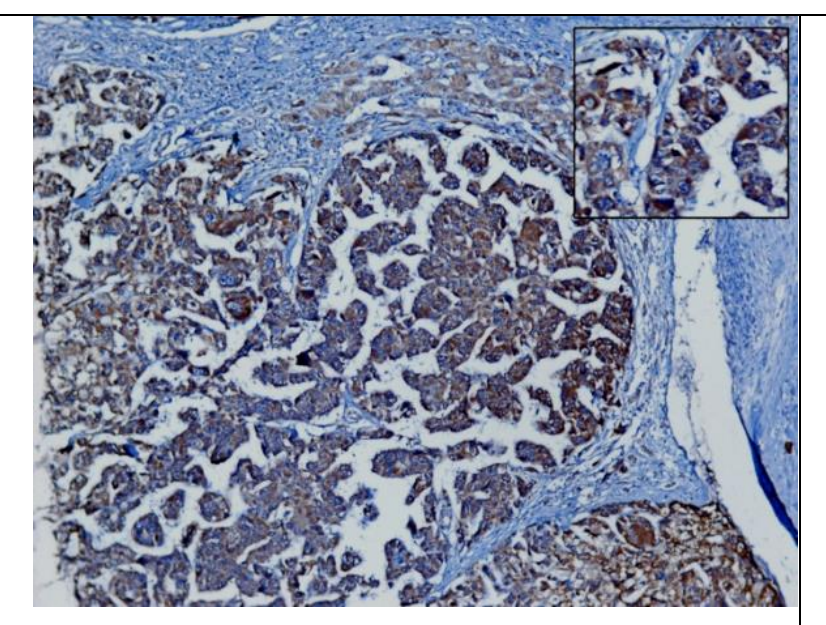

Figure 9: shows Hepatocellular carcinoma on top of cirrhotic nodule, grade I showing positive expression of hepatocytes for MMP1 as brownish stain (arrow) (IHC,DAB, 400).

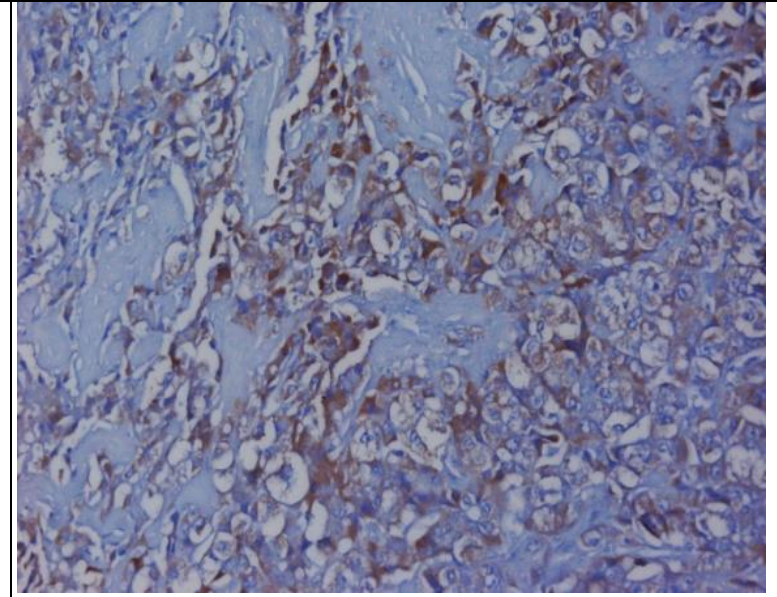

Figure 10 : shows Hepatocellular carcinoma, grade II showing positive expression of hepatocytes for MMP1 as brownish stain (arrow) (IHC,DAB, 400).

\section{Discussion}

Hepatocellular carcinoma (HCC) is the third most common cause of cancer-related deaths in the world (20). This tumor develops in patients with chronic liver diseases, and its etiopathogenesis includes viral infection (hepatitis B and C), alcohol, and aflatoxin B1 consumption (21). Although the diagnostic and surgical approaches have made great progress in recent years, patient survival remains unsatisfactory because of a high incidence of recurrence after hepatic resection or other types of loco-regional therapy (22). The 5year survival rate of HCC is $25-39 \%$ following surgery (23).

The results from our study by analyzing the expression patterns of MMP-1 using immunohistochemistry assay revealed that the high MMP-1 expression levels were both associated with high fibrosis stage, inflammation grading of liver tissues, liver function activities, presence of tumor recurrence and portal vein invasion, suggesting that MMP-1 could be good diagnostic factor represent the liver states under $\mathrm{HCV}$ infection and followed diseases disorder. Our results in agreement with Okamoto et $\boldsymbol{a l}$. (24), who mention that, in one paper, the exprission of the MMP-1 was slightly increased in HCC patients with a background of chronic hepatitis $\mathrm{C}$ virus (HCV)-related liver disease compared to patients with HCV-related chronic liver disease without HCC.
Our data demonstrated that, the expression patterns of MMP-1 is associated with the degree of liver diseases where the expression patterns of MMP-1 in hepatic HCC patients is a very high significant as comparing with that in hepatic cirrhosis patients that in which the expression patterns of MMP-1 is very high significant as comparing with that in hepatic $\mathrm{HCV}$ patients, while the expression patterns of MMP-1 in hepatic HCV elevated but without significant difference as the of collagen is slightly accumulate which degraded with MMP1 (Collaginase1). These agree with Grimm et al. (25) \& Fang et al. (26), who reported that, MMP1 expression has been described in both neoplastic and peritumoral stromal cells; however, its presence is considered more important in the zone of greatest activity corresponding to the tumor .

These results coincide with Liao et al. (27), who noticed that, The results from their study by analyzing the expression patterns of MMP-1 in 106 HCC surgical specimens using immunohistochemistry assay revealed that the high MMP-1 expression levels were both associated with high fibrosis stage, presence of tumor recurrence and portal vein invasion, suggesting that MMP-1 could be independent prognostic factors.

The present data is in parallel with Hatfield et al. (28), who represented that, MMPs, 
as a family of zinc-dependent endopeptidases, are able to degrade virtually any component of the extracellular matrix. MMPs are critical for remodeling the extracellular matrix, thereby affecting cell behavior under physiologic and pathophysiologic circumstances, such as embryogenesis and cancer progression. In this family, MMP-1 initiates degradation of collagen $\mathrm{I}$, which is abundant in the extracellular matrix and is essential for keratinocyte migration; several authors consider that these mechanisms facilitate tumor invasion.

The results explain that, increasing with a high significant differences of ASAT in HCV, cirrhosis and HCC groups as comparing to normal control group, while there is no significant differences in value of ASAT among the $\mathrm{HCV}$, cirrhosis and HCC groups. On the other hand, the values of ALAT increasing with high significant differences in $\mathrm{HCV}$, cirrhosis and HCC groups as comparing to normal control group, while there is no significant differences of values of ALAT among HCV, cirrhosis and HCC groups.

These results agree with Hann $\boldsymbol{e t}$ al. (29), they observe a significant association between ALT and HCC risk in either univariate or multivariate analysis, suggesting the inability of ALT as a prospective predictor of HCC risk in HCV patients. AST exhibited a significant association with HCC risk in the univariate analysis, which disappeared after multivariate analysis adjusting all the major variables including cirrhosis. Similar observations were also noticed for ALP. These data indicated that the associations observed for AST and ALP could be potentially mediated by the presence of liver cirrhosis. (30).

Our data demonstrate that, elevation of ALP values with high significant differences in $\mathrm{HCV}$, Cirrhosis and $\mathrm{HCC}$ groups as comparing to normal control group. In addition to there is elevation of ALP values with high significant differences in HCC in comparing to both $\mathrm{HCV}$ and Cirrhosis groups and there is no significant differences between HCV and Cirrhosis groups.

The data obtained are in coincidence with Giannini et al. (31) whos stated that there are two major types of serum liver enzyme level changes commonly encountered in clinical practice: hepatocellular predominance with elevated ALT and AST, and cholestatic predominance with elevated ALP and GGT. Serum ALT and AST are released from damaged hepatocytes into blood and their activities have been widely recognized as effective tools to detect liver diseases $(\mathbf{3 2} \mathbf{\&} \mathbf{3 3})$. Actually, ALT is the most extensively investigated serum enzyme and elevated ALT has been associated with the mortality in various liver diseases $(32 \& 34)$.

Our data also in coincidence with Aragon and Younossi (35) they noticed that, the joint analysis of GGT with other enzymes may yield additional information regarding disease risk and diagnosis. For example, elevated GGT combined with elevated ALP usually points to hepatobiliary injury, which distinguishes from ALP elevation alone resulting from bone diseases.

Our results agree with Hann et al. (29), reported that, further combined GGT with ALT, AST or ALP to determine if the combined evaluation could improve the predictive power compared to GGT alone. the combined analysis of GGT with ALP markedly increased HCC risk in patients with an elevated level of both enzymes compared to those with a normal value for both enzymes.

Our data agree with Ishizawa et al. (36), who reported that, decreased ALB indicate marked liver damage, while ascites and encephalopathy indicate liver failure and serious portal hypertension. Also agree with Zhao et al. (37) concluded that platelet count, ALP, prealbumin and GGT may be considered as supplemental factors for routine liver function scoring systems.

In the present investigation, the histopathological results indicated that, most patients were in stage $2(28,45.2 \%)$, while stage 1 was represented by few cases $(7,11.3 \%)$. In other words, most of the included patients (55, 88.7\%) had significant fibrosis (i.e., METAVIR stages more than 1). These results indicated, therefore that, $\mathrm{HCV}$ infection has a rapid course of disease progression in the studied population. Similar results were reported in a similar Egyptian population by Mangoud et al. (38). These authors attributed the progressive nature of the disease to the concomitant infection with other viruses like HBV. However, in this study patients with $\mathrm{HBV}$ concomitant infection were 
excluded. Hence, METAVIR stage 1 fibrosis was absent from the study of Mangoud et al. (39) (and METAVIR stage 2 replaced stage 1 in this study instead) due to the rapid course of disease progression caused by other concomitant infections.

These results agree with Alberti $\boldsymbol{e t}$ al. (40) Staging of fibrosis is helpful in determining the duration of treatment. Lesions should be assessed histologically even in patients with persistently normal serum transaminases since advanced fibrosis has been shown in many of these patients.

In conclusion, we find that our results contribute to a better knowledge of the biological characterisation of $\mathrm{HCC}$ with regard to different patterns of expression of MMP1. Moreover, our findings open the possibility to design other studies on the impact of the enzymatic system of MMP1 on prognosis, therefore opening the possibility of future therapeutic targets for this frequent tumour.

\section{References}

1- Parkin DM, Bray F, Ferlay, J, and Pisani, P (2001): Estimating the world cancer burden: Globocan 2000. Int. J. Cancer 94: 153-156.

2- El-Serag HB, and Rudolph KL, (2007): Hepatocellular carcinoma: epidemiology and molecular carcinogenesis. Gastroenterology. 132: 2557-2576.

3- Zhou BB, Zhang H, Damelin M, Geles KG, and Dirks PB, (2009): Tumourinitiating cells: challenges and opportunities for anticancer drug discovery. Nat Rev Drug Discov. 8: 806-823.

4- Tommaso AD (2010): Risk of HCC: Genetic heterogeneity and complex genetics. Journal of Hepatology: vol. 52: j 252-257.

5- Bosch FX, Ribes J, Cleries R, and Diaz $M$ (2005): Epidemiology of hepatocellular carcinoma. Clin Liver Dis;9:191.

6- Ali A and Zein NN (2005): Hepatitis C infection: a systemic disease with extrahepatic manifestations. Cleve Clin J Med;72:1005-1008.

7- Anthony PP and Ishak KG (1978): "The morphology of cirrhosis. Recommendations on definition, nomenclature, and classification by a working group sponsored by the World Health Organization." J Clin Pathol 31(5): 395-414.

8- Davis GL, Albright JE, Cook SF and Rosenberg DM (2003): Projecting future complications of chronic hepatitis $C$ in the United States. Liver Transpl;9:331.

9- Matsunaga Y, Koda M, Murawaki Y (2004): Expression of matrix metalloproiteinases (MMPs) and tissue inhibitors of metalloproteinases (TIMPs) in hepatocellular carcinoma tissue, compared with the surrounding non-tumor tissue. Res Commun Mol Pathol Pharmacol 115-116:143-150

10- Altadill A, Rodríguez $M$ and González LO (2009): Liver expression of matrix metalloproteases and their inhibitors in hepatocellular carcinoma. Dig Liver Dis 41:740-748.

11- Kuo G, Choo QL, Alter H, Gitnick G, and Redeker A, (1989): An assay for circulating antibodies to a major A, non-B hepatitis. Science 244: 362-369.

12- Voller A, Barlett A, and Bidwell DE, (1978): Enzyme immunoassay with special reference to ELISA echnique. J. Clin. Pathol, 31: 507-520.

13- Groner W. and Epstein E, (1982): Counting and sizing of blood cells using light scattering. In Advances In ematological Methods: Eds. Van Assendelft, O.W., J.M. England. Boca Raton. CRC Press, pp: 567-568.

14- Mollay HT, and Evelyn KA, (1937): Determination of bilirubin with photoelectric colorimeter. J. Biol. Chem, 119: 481-485.

15- Henry RJ, Chiamori DC, Gloub O, and Berkman S, (1960): Revised spectrophotometric methods for the determination of glutamicoxaloacetic transaminase, glutamic-pyruvic transaminase and lactic acid ehydrogenase. Amr J Clin Pathol, 34: 381384.

16- Pinnell AE, and Northam BF, (1978): New automated dye-binding method for serum albumin determination with bromocresol purple. Clin. Chem 24(1): 80-86.

17- Quick AJ, (1963): Determination of prothrombin. Am J Clin Pathol, 246: 517-519.

18- Hsu SM and Raine L, (1981): Protein A, avidin, and biotin in immunohistochemistry. J Histochem Cytochem. ,29(11):1349-53

19- Snedecor GW, and Cochran WG, (1989): Statistical Methods, Eighth Edition, Iowa State University Press.

20- Farazi PA, DePinho RA, (2006): Hepatocellular carcinoma pathogenesis: from genes to environment. Nat Rev Canc 6:674-687

21- Thorgeirsson SS, Lee JS, Grisham JW, (2006): Molecular prognostication of liver cancer: end of the beginning. J Hepatol; 44:798.

22- Maheshwari S, Sarraj A, Kramer J, (2007): Oral contraception and the risk of hepatocellular carcinoma. J Hepatol 47:506-513

23- Fan ST, Mau Lo C, Poon RT, (2011): Continuous improvement of survival outcomes of resection of hepatocellular carcinoma: a 20-year experience. Ann Surg 253:745-758

24- Okamoto K, Mandai M, Mimura K, Murawaki Y, Yuasa I. (2005): The association of MMP-1, -3 and -9 genotypes with the prognosis of HCV-related hepatocellular carcinoma patients. Res Commun Mol Pathol Pharmacol;117-118:77-89

25- Grimm M, Lazariotou M, Kircher S (2010): MMP-1 is a (pre-)invasive factor in Barrett-associated 
esophageal adenocarcinomas and is associated with positive lymph node status. J Transl Med 8:99

26- Fang WL, Liang WB, He H, Zhu Y, Li SL, Gao LB, Zhang L. (2010): Association of matrix metalloproteinases 1,7 , and 9 gene polymorphisms with genetic susceptibility to colorectal carcinoma in a Han Chinese population. DNA Cell Biol 29;657-661.

27- Liao M, Zhao J, Zhang Y, Li Z, Wang J, Pan Y, (2012): Prognostic Value of Matrix Metalloproteinase1/Proteinase-Activated Receptor-1 Signaling Axis in Hepatocellular Carcinoma. Pathol. Oncol. Res. 18:397-403.

28- Hatfield KJ, Reikvam H. and Bruserud O, (2010): The crosstalk between the matrix metalloprotease system and the chemokine network in acute myeloid leukemia. Curr Med Chem 17:44484461.

29- Hann H, Wan S, Myers RE, Hann RS, Xing J, Chen B, and Yang $H$ (2012): Comprehensive Analysis of Common Serum Liver Enzymes as Prospective Predictors of Hepatocellular Carcinoma in HBV Patients. PLOS ONE. Volume 7: | Issue $10 \mid$ e47687.

30- Sheth SG, Flamm SL, Gordon FD, Chopra S (1998): AST/ALT ratio predicts cirrhosis in patients with chronic hepatitis $\mathrm{C}$ virus infection. Am J Gastroenterol 93: 44-48.

31- Giannini EG, Testa R, Savarino V (2005): Liver enzyme alteration: a guide for clinicians. CMAJ 172: 367-379.

32- Kim WR, Flamm SL, Di Bisceglie AM, Bodenheimer HC (2008) Serum activity of alanine aminotransferase (ALT) as an indicator of health and disease. Hepatology 47: 1363-1370.

33- Lee JK, Shim JH, Lee HC, Lee SH, Kim KM, (2010): Estimation of the healthy upper limits for serum alanine aminotransferase in Asian populations with normal liver histology. Hepatology 51: 15771583.

34- Tai DI, Lin SM, Sheen IS, Chu CM, Lin DY, (2009): Long-term outcome of hepatitis B e antigennegative hepatitis B surface antigen carriers in relation to changes of alanine aminotransferase levels over time. Hepatology 49: 1859-1867.

35- Aragon G and Younossi ZM (2010): When and how to evaluate mildly elevated liver enzymes in apparently healthy patients. Cleve Clin J Med 77: 195-204.

36- Ishizawa T, Hasegawa K, Kokudo N, Sano K, Imamura H, Beck Y, Sugawara Y, Makuuchi M (2009): Risk factors and management of ascites after liver resection to treat hepatocellular carcinoma. Arch Surg; 144: 46-51

37- Zhao W, Zhang H, Yang N, Fu Y, Qian W, Chen $B$ and Yang G (2012): Preoperative predictors of short-term survival after hepatectomy for multinodular hepatocellular carcinoma. World $J$ Gastroenterol; 18(25): 3272-3281

38- Mangoud AM, Eassa MH, Sabee EI, (2004a): New Concept in Histopathological Grading and Staging of Chronic Hepatitis C Infection in Sharkia Governorate, Egypt. J. Egypt. Soc. Parasitol., 34 (1): 385-400.

39- Mangoud AM, Eassa MH, Sabee EI, (2004b): $\mathrm{HCV}$ and associated concomitant infections at Sharkia Governorate, Egypt. J. Egypt. Soc. Parasitol., 34 (1): s447-458.

40- Alberti A, Noventa F, Benvegnu L, Boccato S. and Gatta A. (2002): Prevalence of liver disease in a population of asymptomatic persons with hepatitis $\mathrm{C}$ virus infection. Ann Intern Med; 137: 961-64. 